\title{
Nematodes and Weeds Control Effects of Pueraria phaseoloides and Flemingia macrophylla Fallows on Establishment, Survival and Yield of Plantain
}

\author{
B. Banful ${ }^{1,2 *}$, S. Hauser ${ }^{1}$, K. Ofori ${ }^{3}$ and F. Kumaga ${ }^{3}$ \\ ${ }^{1}$ Humid Forest Ecoregional Centre, International Institute of Tropical Agriculture (IITA), B. P. \\ 2008, Messa, Yaounde, Cameroon \\ ${ }^{2}$ Crops Research Institute, P. O. Box 3785, Kumasi, Ghana \\ ${ }^{3}$ Crop Science Department, University of Ghana, Legon, Ghana \\ *Corresponding author; E-mail: kbranoh@yahoo.com; b.banful@cropsresearch.org
}

\begin{abstract}
The yield of plantain (Musa spp., AAB Simmonds) declines sharply after 1-2 years of cropping in West and Central Africa, due mainly to weeds and nematodes. A trial was carried out from January 2002 to October 2005 under two landuse systems (LUS) comprising 4-5 year-old bush fallow, dominated by Chromolaena odorata (L.) R. M. King \& H. Rob, and a 20 year-old secondary forest, in three villages in southern Cameroon, to assess the effectiveness of Pueraria phaseoloides and Flemingia macrophylla as planted fallows for weed suppression and reduction in nematode damage of the plantain root system, and determine the yield response of different plantain sucker types to the weed suppression and reduced nematode damage. In each LUS, the treatments were a factorial combination of three levels of fallow system and four levels of plantain sucker type arranged in a randomised complete block design. Total above-ground biomass production of $P$. phaseoloides was $7.45 \mathrm{Mg} \mathrm{ha}^{-1}$, 4.2 times higher than $F$. macrophylla $\left(1.78 \mathrm{Mg} \mathrm{ha}^{-1} ; P<0.05\right)$. The high biomass of $P$. phaseoloides resulted in a significantly greater reduction in total weed biomass compared to F. macrophylla in both wet and dry seasons. Comparing the planted fallows, a sustained reduction in soil nematodes population was only under $P$. phaseoloides. Plantain establishment and survival rates were of decreasing order: PIF (nursery)-derived "Essong" > Boiling water-treated "Essong" > Untreated "Essong”. $P$. phaseoloides produced significantly $(P<0.05)$ the highest plantain yield. There were no differences between the natural regrowth and $F$. macrophylla for all the plantain yield parameters. Sanitizing suckers (boiling and nursery-derived) increased actual yield and quantity of edible bunches by $35 \%$ and $26 \%$, respectively, compared to the untreated. It was concluded that $P$. phaseoloides had the greatest positive effect on the growth and yield of plantain.
\end{abstract}

\section{Introduction}

In West and Central Africa, 25\% of the carbohydrates and 10\% of the food energy of approximately 70 million people are derived from plantains (Ortiz \& Vuylsteke, 1996; Robinson, 1996). In addition, plantain production provides reliable family income and job opportunities (Robinson, 2000). For example, in south-eastern Nigeria, smallholder farmers generate up to $30 \%$ of their income through plantain cultivation (Pasberg-Gauhl \& Gauhl, 1996), while in southern Cameroon and Ghana, plantain is one of the most important food cash crops and, therefore, vital for cash income generation of smallholder farmers (Dury et al., 2002; Schill et al., 1996).

However, yield of plantain declines after 1-2 years of cropping with its attendant economic consequences. The decline usually manifests through stunting of plants, reduction in bunch weight and toppling of plants. Some of the attributable factors are low soil fertility, root damage by nematodes and weeds competition. Application of Pueraria phaseoloides and Flemingia macrophylla as planted fallows have been demonstrated to cause an increase in the yield of associated crops through improved and sustained soil fertility (Kang et al., 1997). Yet, regarding the contribution of these planted fallows to crop yield through nematodes and weeds control, scanty literature is available in West and Central Africa. The paper focuses on these untapped contributory benefits. These benefits might collectively allow increased plantain yields through reduced plant losses, heavier bunches and a longer productive life span.

The objectives of the study, therefore, were to (1) assess the effectiveness of Pueraria phaseoloides and Flemingia macrophylla as planted fallows for weed suppression and reduction in nematode damage of the plantain root system, and (2) determine the yield response of different plantain sucker types to the weed suppression and reduced nematode damage. 


\section{Materials and methods}

Experimental sites

Experiments were carried out in three villages in southern Cameroon: Mfou ( $3^{\circ} 57^{\prime} \mathrm{N}, 11^{\circ} 48^{\prime} \mathrm{E}$ ),

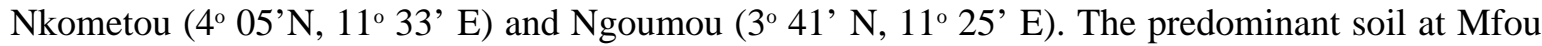
and Ngoumou is clayey, kaolinitic, Typic Kandiudult (Hulugalle \& Ndi, 1993) while at Nkometou the soil is kaolinitic, Rhodic Kandiudult (Thenkabil, 1999). Average annual precipita-tion ranges from $1510 \mathrm{~mm}$ at Nkometou to $1642 \mathrm{~mm}$ at Ngoumou. All the villages have a bimodal rainfall distribution, with peaks in June and September. The first and second growing seasons typically last from mid-March to mid-July and from mid-August to the end of November, respectively, separated by a short dry spell of about 4 weeks in July. The major dry season starts in mid-November and lasts to the end of February or middle of March.

In each village, experiments were laid out in two land use systems (LUS) comprising 4-5 yearold bush fallow dominated by Chromolaena odorata (L.) R. M. King \& H. Rob, and a 20 year-old secondary forest. Before planting F. macrophylla and P. phaseoloides, samples were collected per plot at depths of 0-10 cm, 10-20 cm and 20-30 cm for chemical analyses. A composite of nine samples at the same depth was made to obtain one sample per plot. The samples were air-dried and ground, mixed thoroughly and sub-sampled for the analyses.

The following procedures were adopted for the analyses: $p H$ was determined in 1:2.5 $(\mathrm{w} / \mathrm{v})$ soil:water suspension. Exchangeable basic cations, $\mathrm{Ca}^{2+}, \mathrm{Mg}^{2+}, \mathrm{K}^{+}$and available phosphorus were extracted by the Mehlich-3 procedure (Mehlich, 1984). The exchange-able cations were determined by atomic absorption spectrophotometry and available phosphorus by the molybdate blue procedure described by Murphy \& Riley (1962). Organic carbon was determined using improved Heanes digestion and spectro-photometric procedure (Heanes, 1984). Total nitrogen was determined from a wet acid digest (Buondonno et al., 1995) by colorimetric analysis (Anderson \& Ingram, 1993). The chemical properties of the bush and forest soils are summarized in Table 1.

TABLE 1

Chemical composition of soils in bush and forest land-use systems

\begin{tabular}{|c|c|c|c|c|c|c|}
\hline $\mathrm{p} H\left(\mathrm{H}_{2} \mathrm{O}\right)$ & $\begin{array}{c}\text { Total } N \\
g k^{-1}\end{array}$ & $\begin{array}{l}\text { Organic } C \\
\qquad \mathrm{~kg}^{-1}\end{array}$ & $\begin{array}{c}\text { Available } P \\
\quad \mathrm{mg} \mathrm{kg}^{-1}\end{array}$ & $\begin{array}{c}\mathrm{Ca} \\
\mathrm{cmol} \mathrm{kg}^{-1}\end{array}$ & $\begin{array}{c}\mathrm{Mg} \\
\mathrm{Cmol} \mathrm{kg}\end{array}$ & $\begin{array}{c}K \\
\mathrm{cmol} \mathrm{kg}^{-1}\end{array}$ \\
\hline \multicolumn{7}{|c|}{ 0-10 cm depth } \\
\hline 4.9 & 1.6 & 26.2 & 17.2 & 4.0 & 1.6 & 0.3 \\
\hline 4.6 & 1.9 & 29.8 & 26.1 & 3.2 & 1.3 & 0.3 \\
\hline \multicolumn{7}{|c|}{ 10-20 cm depth } \\
\hline 4.7 & 1.4 & 23.1 & 12.0 & 3.1 & 1.3 & 0.2 \\
\hline 4.2 & 1.6 & 24.8 & 16.0 & 2.5 & 1.0 & 0.3 \\
\hline \multicolumn{7}{|c|}{ 20-30 cm depth } \\
\hline 4.2 & 0.9 & 15.4 & 3.5 & 1.4 & 0.6 & 0.1 \\
\hline 3.9 & 0.8 & 15.8 & 3.5 & 0.6 & 0.4 & 0.2 \\
\hline
\end{tabular}

\section{Experimental procedure}

Fields were slashed in January and burned in mid to late February 2002. In each LUS, the treatments were a factorial combination of three levels of fallow system and three levels of plantain sucker type. The fallow systems comprised $F$. macrophylla alley cropping, $P$. phaseoloides cover cropping and cropping in natural regrowth. The plantain sucker types were PIF (nursery)-derived "Essong" sucker, boiling water-treated "Essong" sucker and untreated "Essong" sucker. "Essong" is the local name for French plantain in Cameroon. A randomized complete block design with three replications was used. Each plot measured $15 \mathrm{~m} \times 12 \mathrm{~m}$. Planting of the leguminous fallows was in early June 2002 at Nkometou, mid-June at Mfou and late June at Ngoumou. 
The F. macrophylla hedgerows were planted by drilling seeds at $4 \mathrm{~kg} \mathrm{ha}^{-1}$ in rows of $12 \mathrm{~m}$ length and $3 \mathrm{~m}$ apart. P. phaseoloides was established by drilling seed at $12 \mathrm{~kg} \mathrm{ha}^{-1}$ in four double rows spaced $1 \mathrm{~m}$ between two rows and $2 \mathrm{~m}$ between adjacent double rows. This planting pattern was adopted with a view to establishing plantain in the alleys of the hedgerows and the space between the adjacent double rows. Planting holes for plantain measuring $30 \mathrm{~cm} \times 30 \mathrm{~cm} \times 30 \mathrm{~cm}$ were prepared between 20th March and 5th April 2003 in the three villages. The holes were spaced $3 \mathrm{~m}$ between rows and $2 \mathrm{~m}$ within rows, giving 1667 plants ha $^{-1}$. At Mfou, planting was done between 12th and 21st May 2003 in both bush and forest LUS. At Nkometou, planting was between 24th and 30th May 2003 in both LUS while at Ngoumou, planting was between 5th and 11th June 2003 in the two LUS. There were 30 plants per plot.

\section{Planted fallows biomass assessment}

At 11, 14, 18 and 20 months after planting (MAP), biomass of $P$. phaseoloides cover crop and $F$. macrophylla hedgerows were determined. For $F$. macrophylla $a_{2}$ the hedgerows were cut in rows to about $30 \mathrm{~cm}$ above soil level. $P$. phaseoloides above-ground biomass was sampled in $0.75 \mathrm{~m} \times$ $0.75 \mathrm{~m}$ quadrats using a systematic sampling system and nine samples were taken per plot. Total dry weight of each biomass was determined from sub-samples dried at $65{ }^{\circ} \mathrm{C}$ to constant weight. The fresh biomass after cutting were applied as mulch in the plots from which they originated.

\section{Assessment of weed biomass}

Weed biomass was assessed in the wet season (11 and18 MAP) and at the end of the dry season (23 MAP) under $P$. phaseoloides and F. macrophylla in all plots. Nine samples of $0.75 \mathrm{~m} \times 0.75 \mathrm{~m}$ were taken per plot using a systematic sampling system. All above-ground live biomass was sampled and separated into broad leaves and grasses. Total dry weight of each group was determined from sub-samples dried at $65{ }^{\circ} \mathrm{C}$ to constant weight. The remaining weed cover were slashed after each sampling.

\section{Assessment of soil nematode populations and nematode root damage}

Before planting of the fallow species (0 MAP), nine soil cores of $0-10 \mathrm{~cm}$ depth were collected in a stratified pattern per plot to assess pathogenic nematode populations. Two subsequent soil samplings at the same depth at 12 and 24 MAP were also collected for the nematodes populations assessment. The soil cores from each plot were thoroughly mixed to obtain a composite sample from which $200 \mathrm{~cm}^{3}$ were taken, sealed in polythene bags and stored in a refrigerator until nematode extraction. The nematodes were extracted using a modified Baermann funnel method (Hoopers, 1990). Nematode root damage was assessed at harvest on every plantain plant using a method adapted from Broadley (1979), as reviewed by Bridge \& Gowen (1993).

Assessment of plantain establishment, survival, growth and yield

Plantain establishment and survival counts were made at 10 and 52 weeks after planting, respectively. Counts were expressed in percentages. Growth measure-ments were made on the 12 central plants per plot at 6 months after planting of plantain and subsequently at 6 months interval. Yield data were taken at harvest. The growth parameters considered included plant height, pseudostem girth at $50 \mathrm{~cm}$ above soil level, number of suckers per plant, total leaf area measured from the third fully opened leaf and calculated from the formula of Kumar et al. (2001):

$$
\mathrm{TLA}=\mathrm{L} \times \mathrm{B} \times 0.80 \times \mathrm{N} \times 0.662 \ldots(1) ;
$$

where TLA = total leaf area, $\mathrm{L}=$ length of third fully opened leaf, $\mathrm{B}=$ widest width of third fully opened leaf, and $\mathrm{N}=$ total number of functional leaves. At harvest the data considered were plant height, pseudostem girth, number of functional leaves, number of days to flowering, number of days to harvest, bunch weight, number of harvested plants, number of failed plants, actual yield ha ${ }^{-1}$ and potential yield ha-1.

\section{Statistical analyses}


Data were analysed by analysis of variance (ANOVA), using the general linear model (GLM) procedure of SAS (SAS, 1997). Numbers of nematodes per $100 \mathrm{~cm}^{3}$ of soil were $\log (\mathrm{x}+1)$ transformed. Counts data were arcsine transformed. Least significant differences (LSD) were calculated and the probability of treatment means being significantly different was set at $P=0.05$. The repeated function was used to test for time differences and the test criterion used was Wilks' Lambda (SAS, 1989).

\section{Soil chemical characteristics}

\section{Results}

The forest land-use system (LUS) had higher content of total nitrogen, organic $\mathrm{C}$ and available $\mathrm{P}$ than the bush LUS at the $0-10 \mathrm{~cm}$ and $10-20 \mathrm{~cm}$ depths (Table 1). At the 20-30 cm depth, total nitrogen, organic $\mathrm{C}$ and available $\mathrm{P}$ were similar in both bush and forest LUS. Calcium and magnesium remained higher in the bush than in the forest LUS across the $0-30 \mathrm{~cm}$ depth.

Biomass production of $\mathrm{P}$. phaseoloides and $\mathrm{F}$. macrophylla

After 20 months of growth, there was significant $(P<0.05)$ fallow system $\times$ LUS interaction for $P$. phaseoloides (Table 2). The biomass of $P$. phaseoloides was higher in the bush than in the forest, the difference being $20.7 \%$. The F. macrophylla biomass in the bush was $11.8 \%$ higher than in the forest. There was also significant fallow system $\times$ village interaction (Table 2) such that the relative difference in biomass produced between $P$. phaseoloides and $F$. macrophylla changed from one village to another. The highest biomass of $P$. phaseoloides was at Mfou (8.7 $\mathrm{Mg} \mathrm{ha}^{-1}$ ), while the lowest biomass produced for F. macrophylla was at the same village.

TABLE 2

Biomass yield of Flemingia macrophylla and Pueraria phaseoloides in land-use systems and villages at 20 months

Biomass yield $\left(\mathrm{Mg} \mathrm{ha}^{-1}\right)$

Fallow system

\begin{tabular}{lccc} 
Land use system & F. macrophylla & P. phaseoloides & Mean \\
Bush & 1.9 & 8.2 & 5.0 \\
Forest & 1.7 & 6.8 & 4.2 \\
Mean & 1.8 & 7.5 & \\
& & & \\
LSD $(P=0.05)$ & Land use system (LUS) $=0.52$ & ; Fallow system (FS) $=0.52$; LUS $\times$ FS $=0.73$ \\
Villages & F. macrophylla & P. phaseoloides & Mean \\
Ngoumou & 1.8 & 7.0 & 4.4 \\
Mfou & 1.5 & 8.7 & 5.1 \\
Nkometou & 2.0 & 6.7 & 4.3 \\
Mean & 1.8 & 7.5 & \\
\multicolumn{2}{r}{ LSD $(P=0.05)$}
\end{tabular}

Weed population dynamics

At 11 MAP in the first wet season of 2003, broad leaf weed biomass was significantly $(P<0.05)$ affected by the interactive effects of fallow system and LUS across the three villages (Table 3a). Pueraria phaseoloides in both bush and forest LUS had the least biomass of broad leaf weeds, significantly lower than in F. macrophylla and the natural regrowth in both LUS. Broad leaf weeds dominated by Chromolaena odorata accounted for over 95\% of the total weeds in P. phaseoloides and about $84 \%$ of the weeds in F. macrophylla. Significant fallow system $\times$ LUS interactions were also observed in the grass biomass such that $P$. phaseoloides in both LUS had significantly $(P<$ 0.05 ) lower grass biomass than in F. macrophylla in the bush. Furthermore, the grass biomass in the natural regrowth in both LUS was at least 2.2 times less than in F. macrophylla in the bush (Table 3a).

West African Journal of Applied Ecology, vol. 14, 2008 
TABLE 3a

Weed biomass of planted fallows and in natural regrowth in land-use systems at 11 MAP across three villages

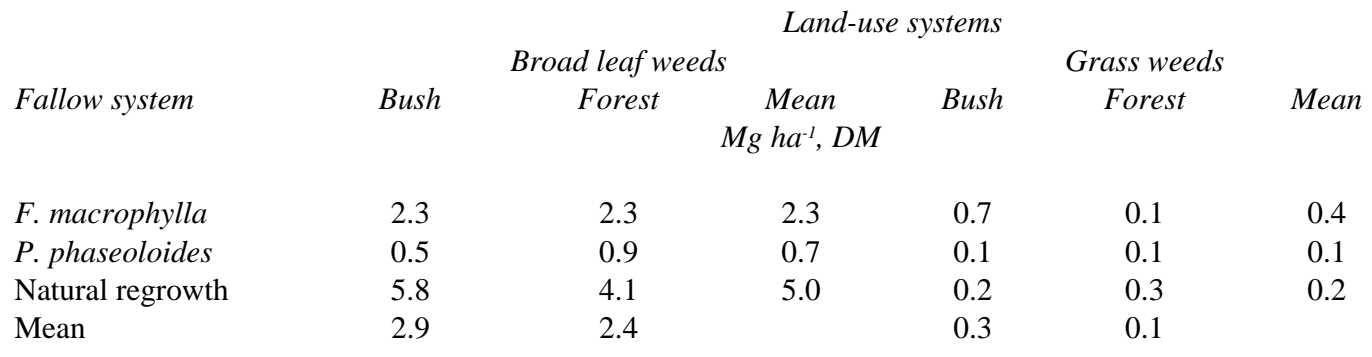

$$
\begin{array}{cll}
\text { LSD }(P=0.05) & \begin{array}{l}
\text { Land use system }(\mathrm{LUS})=0.29 ; \\
\text { Fallow system }(\mathrm{FS})=0.36 ;
\end{array} & \text { Land use system }(\mathrm{LUS})=0.13 ; \\
\text { LUS } \times \text { FS }=0.57 . & \text { LUS } \times \text { FS }=0.57 .
\end{array}
$$

Interactions between fallow system and village for broadleaf weeds was significant $(P<0.05)$ at 18 MAP in the second wet season of 2003. The least biomass for broad leaf weeds was recorded in $P$. phaseoloides system at Ngoumou while the largest was in F. macrophylla system at Nkometou (Table 3b). There were no significant interactions for the grass biomass at 18 MAP. Flemingia macrophylla system contained the highest weight $\left(0.4 \mathrm{Mg} \mathrm{ha}^{-1}\right)$ while $P$. phaseoloides had the lowest weight $\left(0.1 \mathrm{Mg} \mathrm{ha}^{-1}\right)$. Additionally, significantly lower grass weight were recorded in the forest $\left(0.1 \mathrm{Mg} \mathrm{ha}^{-1}\right)$ than the bush $\left(0.2 \mathrm{Mg} \mathrm{ha}^{-1}\right)$ as well as at Ngoumou $\left(0.1 \mathrm{Mg} \mathrm{ha}^{-1}\right)$ village compared to the other villages (Mfou, $0.3 \mathrm{Mg} \mathrm{ha}^{-1}$; Nkometou, $0.2 \mathrm{Mg} \mathrm{ha}^{-1}$ ) (Table 3c).

TABLE 3b

Biomass of broad leaf weeds of planted fallows and in natural regrowth at three villages at 18 MAP across land use systems

$\begin{array}{lcccc}\text { Fallow systems } & \text { Ngoumou } & \text { Millages } & \text { Mean } \\ & & & \text { Nkometou } & \\ \text { F. macrophylla } & 0.46 & 1.12 & 2.72 & 0.43 \\ \text { P. phaseoloides } & 0.09 & 0.58 & 1.37 & 1.90 \\ \text { Natural regrowth } & 0.73 & 1.93 & 3.05 & 2.38 \\ \text { Mean } & 0.42 & 1.21 & \\ & & & \end{array}$

TABLE 3C

Grass weed biomass in fallow systems, villages and land-use systems at 18 MAP

$$
\operatorname{Biomass}\left(\mathrm{Mg} \mathrm{ha}^{-1}, \mathrm{DM}\right)
$$

$\begin{array}{lc}\text { Fallow system } & \\ \text { F. macrophylla } & 0.4 \\ P \text {. phaseoloides } & 0.1 \\ \text { Natural regrowth } & 0.1 \\ \text { LSD }(P=0.05) & 0.13 \\ \text { Village } & \\ \text { Ngoumou } & 0.1 \\ \text { Mfou } & 0.3 \\ \text { Nkometou } & 0.2 \\ \text { LSD }(P=0.05) & 0.10\end{array}$

West African Journal of Applied Ecology, vol. 14, 2008 


$\begin{array}{lc}\text { Land-use system } & \\ \text { Bush } & 0.2 \\ \text { Forest } & 0.1 \\ \text { LSD }(P=0.05) & 0.10\end{array}$

After the dry season (23 MAP), the lowest total weed biomass was recorded in $P$. phaseoloides while the highest biomass was in the natural regrowth. With the shift from the wet to the dry season, broad leaf biomass in $P$. phaseoloides system increased significantly $(P<0.05)$ in both bush and forest LUS (Table 4). This increase notwithstanding, $P$. phaseoloides still recorded the lowest broad leaf weeds biomass in the dry season compared to F. macrophylla and natural regrowth. The biomass of grass was not affected by the seasonal change under the three fallow systems.

TABLE 4

Changes in broadleaf weed biomass over seasons in planted fallows and in natural regrowth in two land-use systems

\begin{tabular}{|c|c|c|c|c|}
\hline \multirow[b]{2}{*}{ Land-use systems } & \multirow[b]{2}{*}{ Fallow systems } & \multicolumn{2}{|c|}{$\begin{array}{c}\text { Season } \\
\text { Biomass } M g \text { ha }^{-1}\end{array}$} & \multirow{2}{*}{$\begin{array}{l}\text { Wilks' Lambda test - } \\
\text { (P values) } \\
\text { Wet to dry }\end{array}$} \\
\hline & & Wet & Dry & \\
\hline \multirow[t]{3}{*}{ Bush } & F. macrophylla & 1.2 & 1.5 & $0.002 * *$ \\
\hline & P. phaseoloides & 0.7 & 1.1 & $0.021 *$ \\
\hline & Natural regrowth & 1.9 & 1.8 & $0.695 \mathrm{~ns}$ \\
\hline \multirow[t]{3}{*}{ Forest } & F. macrophylla & 1.7 & 2.0 & $0.086 \mathrm{~ns}$ \\
\hline & P. phaseoloides & 0.7 & 1.3 & $0.012 *$ \\
\hline & Natural regrowth & 1.9 & 2.0 & $0.347 \mathrm{~ns}$ \\
\hline
\end{tabular}

Nematodes population dynamics under fallow systems

Two parasitic nematodes of plantain, Helicotylenchus multicinctus (Cobb) Golden and Meloidogyne incognita, were present in soil of the bush and forest LUS at all three villages. However, the population of $M$. incognita was extremely low (mean of $8.6100 \mathrm{~cm}^{-3}$ ) and was not considered in the results.

At 0 MAP, significant $(P<0.05)$ land-use systems (LUS) $\times$ village interactions were found in soil population of $H$. multicinctus. Ngoumou-bush LUS had 850 times $\left(511.8100 \mathrm{~cm}^{-3}\right)$ more of the nematode than at Mfou-forest LUS $\left(0.6100 \mathrm{~cm}^{-3}\right)$ which had the least. At the villages, a significant positive correlation was found between $H$. multicinctus population and total annual rainfall $(r=$ $0.79 ; P=0.01 ; n=9)$.

At 12 MAP, there was significant $(P<0.05)$ interaction between fallow system and village for $H$. multicinctus soil population. The nematode population under F. macrophylla at Ngoumou (185.9 $\left.100 \mathrm{~cm}^{-3}\right)$ was more than 10 times than under $P$. phaseoloides at Nkometou $\left(16.5100 \mathrm{~cm}^{-3}\right)$ (Table 5). This notwithstanding, the planted fallows recorded significantly lower densities of $H$. multicinctus compared with the natural regrowth. In the villages, population of $H$. multicinctus under $P$. phaseoloides was consistently low, except at Mfou. At 24 MAP, there was significant land-use systems (LUS) $\times$ village interaction due to differences in the bush and not in the forest. The bush at Ngoumou (463.6 $100 \mathrm{~cm}^{-3}$ ) was 2.6 times and 8.5 times significantly higher than the bush at Mfou (178.6 $\left.100 \mathrm{~cm}^{-3}\right)$ and Nkometou (54.4 $\left.100 \mathrm{~cm}^{-3}\right)$, respectively.

TABLE 5

Soil population (per $100 \mathrm{~cm}^{3}$ ) of Helicotylenchus multicinctus under fallow systems and villages at 12 MAP of planted fallows 


\begin{tabular}{lccrr} 
& & \multicolumn{2}{c}{ Villages } & Mean \\
Fallow systems & Ngoumou & Mfou & Nkometou & 76.1 \\
F. macrophylla & 185.9 & 18.5 & 23.8 & 44.7 \\
P. phaseoloides & 85.3 & 32.4 & 16.5 & 152.6 \\
Natural regrowth & 272.7 & 82.3 & 102.9 & \\
Mean & 181.3 & 44.4 & 47.7
\end{tabular}

$$
\text { LSD }(P=0.05) \text { Village }(\mathrm{V})=53.75 ; \text { Fallow system }(\mathrm{FS})=53.75 ; \mathrm{V} \times \mathrm{FS}=93.09
$$

Within 1 year, both $P$. phaseoloides and $F$. macrophylla significantly $(P<0.05)$ reduced density of $H$. multicinctus (Table 6). However, density of $H$. multicinctus under $F$. macrophylla significantly $(P<0.05)$ increased between 12 and 24 MAP while under $P$. phaseoloides the populations were similar within the same period. Over a 2 year period (0-24 MAP), however, the population under $P$. phaseoloides remained significantly $(P<0.05)$ reduced. Under the natural regrowth, the nematode population was similar over the entire 2-year period.

TABLE 6

Changes of Helicotylenchus multicinctus population densities over time under planted fallows and the natural regrowth

\begin{tabular}{lcccccc} 
& \multicolumn{3}{c}{$\begin{array}{c}\text { Time } \\
\text { Population per } 100 \mathrm{~cm}^{3}\end{array}$} & \multicolumn{3}{c}{$\begin{array}{c}\text { Wilks' Lambda test } \\
\text { (P values) }\end{array}$} \\
Fallow systems & Initial (0 MAP) & 12 MAP & 24 MAP & $0-12$ & $12-24$ & $0-24$ \\
& & & & & & \\
Pueraria sp. & 186.6 & 44.7 & 77.2 & $0.014 *$ & $0.112 \mathrm{~ns}$ & $0.013 *$ \\
Flemingia sp. & 140.3 & 76.1 & 155.9 & $0.008 * *$ & $0.030 *$ & $0.953 \mathrm{~ns}$ \\
Nat. regrowth & 107.3 & 152.6 & 147.6 & $0.083 \mathrm{~ns}$ & $0.461 \mathrm{~ns}$ & $0.075 \mathrm{~ns}$
\end{tabular}

*, ** : Significant at $P<0.05$ and $P<0.01$, respectively.

Plantain sucker establishment and survival rates

There was significant $(P<0.05)$ sucker type $\times$ village interaction in plantain establishment, 10 weeks after planting (WAP). Plant establishment was signifi-cantly better in PIF-”Essong” and Boiled-"Essong" at Ngoumou than in the "Essong" boiled at both Mfou and Nkometou (Table 7). The untreated sucker at Ngoumou produced the least established plants. Generally, the order of establishment was PIF-derived "Essong" (95.93\%) > Boiling water-treated "Essong" (86.05\%) > Untreated "Essong" (75.37\%). Significantly, more suckers also established at Mfou (92.50\%) than at Ngoumou (89.26\%) and Nkometou (85.70\%).

TABLE 7

Establishment (10 WAP) and survival patterns (52 WAP) of different sucker types at three villages

\begin{tabular}{|c|c|c|c|c|}
\hline Establishment (10 weeks after planting) & & $\begin{array}{c}\text { Percent plants } \\
\text { Villages }\end{array}$ & & \\
\hline Sucker type & Ngoumou & Mfou & Nkometou & Mean \\
\hline Boiled Essong & 96.3 & 85.4 & 76.5 & 86.1 \\
\hline PIF Essong & 95.2 & 95.4 & 97.2 & 95.9 \\
\hline Untreated Essong & 65.6 & 89.8 & 70.8 & 75.4 \\
\hline Mean & 89.3 & 92.5 & 85.7 & \\
\hline \multicolumn{5}{|l|}{ Survival (52 weeks after planting) } \\
\hline Sucker type & Ngoumou & Mfou & Nkometou & Mean \\
\hline Boiled Essong & 90.4 & 78.2 & 44.4 & 71.0 \\
\hline PIF Essong & 72.2 & 82.0 & 77.4 & 77.2 \\
\hline Untreated Essong & 43.0 & 76.1 & 44.6 & 54.6 \\
\hline Mean & 76.1 & 82.7 & 63.5 & \\
\hline
\end{tabular}

West African Journal of Applied Ecology, vol. 14, 2008 


\begin{tabular}{|c|c|c|c|c|}
\hline & & & LSD & 05) \\
\hline & & & Establishment & Survival \\
\hline Village & & & 2.06 & 3.60 \\
\hline Sucker type & & & 2.38 & 4.16 \\
\hline Village $\times$ Sucker type & 4.12 & 7.20 & & \\
\hline
\end{tabular}

At 52 WAP, the interactive effects of village and sucker type were also significant $(P<0.05)$ (Table 7). Boiled-”Essong” at Ngoumou had the highest survival rate of $90.4 \%$, significantly different from the rates of the other sucker types in all three villages. The least rates were found in the untreated sucker at Ngoumou and Nkometou and also in the boiled sucker at Nkometou. The pattern of sucker survival rates was generally similar to the order of the establishment, though the rates were lower.

Growth and yield of different sucker types under fallow systems

Six months after planting (MAP), significant $(P<0.05)$ village $\times$ sucker type and village $\times$ fallow system interactions were observed only for plantain leaf area (Table 8). Plants of boiled suckers at Ngoumou had significantly larger leaf area than the other plants, the mean difference being 76.1\%. PIF- "Essong” and untreated plants at Nkometou had the least leaf area. Also plants under P. phaseoloides at both Ngoumou and Mfou produced significantly larger leaf area than the other systems while the smallest leaf area was produced by plants under natural regrowth at Nkometou.

TABLE 8

Total leaf area of Essong plantain at 6 MAP

\begin{tabular}{|c|c|c|c|c|c|c|c|c|}
\hline \multirow{3}{*}{ Village } & \multicolumn{3}{|c|}{ Sucker type } & \multicolumn{5}{|c|}{ Fallow system } \\
\hline & Boiled & PIF & Untreated & Mean & F. macrophylla & P. phaseoloides & $\begin{array}{l}\text { Nat. } \\
\text { regrowth }\end{array}$ & Mean \\
\hline & & & & & $m^{2}$ & & & \\
\hline Ngoumou & 1.15 & 0.61 & 0.67 & 0.81 & 0.60 & 1.16 & 0.67 & 0.81 \\
\hline Mfou & 0.96 & 0.65 & 0.86 & 0.82 & 0.67 & 1.28 & 0.53 & 0.82 \\
\hline Nkometou & 0.55 & 0.48 & 0.43 & 0.49 & 0.50 & 0.58 & 0.39 & 0.49 \\
\hline Mean & 0.89 & 0.58 & 0.65 & & 0.59 & 1.00 & 0.53 & \\
\hline $\operatorname{Lsd}(P=0.05)$ & \multicolumn{5}{|c|}{$\begin{array}{l}\text { Village = } 1441.50 \\
\text { Sucker type }=1441.50\end{array}$} & \multicolumn{3}{|c|}{$\begin{array}{l}\text { Village }=1441.50 ; \\
\text { Fallow system }=1441.50 ;\end{array}$} \\
\hline \multicolumn{4}{|c|}{ Village $\times$ Sucker type $=789.56$} & & & \multicolumn{3}{|c|}{ Village $\times$ Fallow system $=789.56$} \\
\hline
\end{tabular}

Also at 6 MAP, significant $(P<0.05)$ village $\times$ land-use systems (LUS) interac-tions were observed for plant height and pseudostem girth (Table 9). Plants from Ngoumou forest were significantly taller than those from Mfou and Nkometou in both bush and forest land-use systems. Furthermore, plants from Ngoumou forest had significantly bigger pseudostem girth than those from Nkometou in both bush and forest land-use systems. Sucker type and fallow systems, however, showed significant differences only as individual factors for plant height and pseudostem girth. The boiled plants were about $16 \%$ taller and $12 \%$ bigger than the mean of the PIF- "Essong" and Untreated "Essong” plants. Plantains under $P$. phaseoloides were also about $25.3 \%$ taller and $25.53 \%$ bigger than the plants under $F$. macrophylla and the natural regrowth.

TABLE 9

Plant height and pseudostem girth of Essong plantain at 6 MAP

Village Bush Forest Mean

Plant height (cm)

West African Journal of Applied Ecology, vol. 14, 2008 


\begin{tabular}{|c|c|c|c|}
\hline Ngoumou & 63.9 & 91.1 & 77.5 \\
\hline Mfou & 71.4 & 82.0 & 76.7 \\
\hline Nkometou & 56.3 & 69.1 & 62.7 \\
\hline Mean & 63.8 & 80.8 & \\
\hline $\operatorname{LSD}(P=0.05)$ & \multicolumn{3}{|c|}{ Land-use $=4.94$; Village $=6.05$; Land-use $\times$ village $=8.55$} \\
\hline Village & Bush & Forest & Mean \\
\hline \multicolumn{4}{|c|}{ Pseudostem girth (cm) } \\
\hline Ngoumou & 15.4 & 19.6 & 17.5 \\
\hline Mfou & 17.1 & 18.2 & 17.6 \\
\hline Nkometou & 14.6 & 15.5 & 15.1 \\
\hline Mean & 15.7 & 17.8 & \\
\hline
\end{tabular}

At both 12 and 18 MAP, however, there were no significant interactions. Boiled plants were significantly taller with bigger pseudostem girth and higher number of functional leaves than the untreated but similar to PIF plants. In addition, plants under $P$. phaseoloides were significantly taller with bigger pseudostem girth than plants under both F. macrophylla and the natural regrowth. The forest produced significantly taller plants with bigger girth, high number of functional leaves and daughter suckers as compared to plants in the bush.

Flowering of the plant-crop started 18.4 MAP and stretched to 21.3 MAP (Table 10). Significant $(P<0.05)$ differences in flowering and yield were observed only in the individual factors under study. Flowering and, subsequently, harvesting were earliest under $P$. phaseoloides, significantly different from that under the natural regrowth. However, the fruit filling period was longer under $P$. phaseoloides than under both $F$. macrophylla and the natural regrowth. The percentage of plants that produced edible bunches was unexpectedly low, the highest of $16.3 \%$ being under $P$. phaseoloides and the least of $9.8 \%$ under the natural regrowth. The high percentage of failed plants comprised dead, uprooted, non-flowering plants and those with pseudostem breakage before flowering or before fruits were edible. These events were similar under the fallow systems. Additionally, the fallow systems did not affect the percentage of edible fruits produced.

TABLE 10

Yield and components of yield of Essong landrace under planted fallows and the natural regrowth

\begin{tabular}{lcccc} 
Variable & \multicolumn{3}{c}{ Fallow systems } \\
& P. phaseoloides & F. macrophylla & Nat. regrowth & LSD $(P=0.05)$ \\
Months to flowering & 18.4 & 19.9 & 21.3 & 1.53 \\
Months to harvesting & 21.2 & 22.3 & 23.8 & 1.62 \\
Fruit filling period (months) & 2.9 & 2.5 & 2.5 & 0.26 \\
Percent plants produced & 16.3 & 10.4 & 9.8 & 5.25 \\
Number of suckers & 4.0 & 3.3 & 3.5 & 0.63 \\
NDRI * & 22.4 & 162.7 & 172.4 & 57.39 \\
Bunch weight (kg) & 9.6 & 7.1 & 8.0 & 1.38 \\
Actual yield (Mg ha $\left.{ }^{-1}\right)$ & 1.3 & 1.2 & 1.1 & 0.16 \\
Potential yield (Mg ha ${ }^{-1}$ ) & 16.0 & 11.8 & 13.2 & 2.29 \\
& & & &
\end{tabular}

The highest number of daughter suckers were produced under $P$. phaseoloides. The nondamaged root index (NDRI) was significantly higher for plants under $P$. phaseoloides than $F$. macrophylla and the natural regrowth. The actual yield of the plant-crop was composed of the West African Journal of Applied Ecology, vol. 14, 2008 
proportion of bunch-producing plants and bunch weight and plantain under $P$. phaseoloides had significantly the highest yield. There were no significant differences between the natural regrowth and F. macrophylla in all the yield parameters studied. The potential yields (expected yields on per hectare basis), however, reflected the expectations of the various treatments.

There were significant $(P<0.05)$ differences between the villages in the percentage of bunchbearing plants that had been uprooted, the RNI (root necrosis index) and the percentage of edible bunches. Ngoumou had significantly higher percentage of uprooted plants and higher RNI than the other villages. On the other hand, Nkometou recorded significantly more edible bunches than Mfou and Ngoumou.

Among the sucker types, boiled and PIF plants flowered later than the untreated plants but had longer fruit filling periods which culminated in significantly $(P<0.05)$ higher bunch yields than the untreated (Table 11). Moreover, both boiled and PIF plants had significantly higher NDRI and living roots than the untreated plants. The number of living roots accounted for $37 \%$ of the variation in plant bunch weight ( $\mathrm{Y}=0.4738$ (number of living roots) $-2.173 ; P=0.007 ; n=18$ ).

TABLE 11

Plant height, pseudostem girth, yield and components of yield of different Essong sucker types

\begin{tabular}{|c|c|c|c|c|}
\hline Variable & $P I F$ & Boiled & $\begin{array}{c}\text { Sucker types } \\
\text { Untreated }\end{array}$ & $\operatorname{LSD}(P=0.05)$ \\
\hline Plant height (cm) & 288.5 & 285.0 & 251.9 & 23.32 \\
\hline Pseudostem girth (cm) & 57.2 & 56.4 & 50.1 & 4.41 \\
\hline Months to flowering & 20.8 & 20.5 & 18.1 & 1.53 \\
\hline Months to harvesting & 23.6 & 23.2 & 20.5 & 1.62 \\
\hline Fruit filling period (months) & 2.8 & 2.7 & 2.4 & 0.26 \\
\hline Percent plants produced & 15.0 & 17.2 & 8.9 & 4.70 \\
\hline Percent edible bunches & 83.8 & 74.4 & 60.9 & 14.16 \\
\hline Percent broken plants with bunch & 22.8 & 28.2 & 26.7 & 12.61 \\
\hline Number of living roots & 9.6 & 8.6 & 7.2 & 0.90 \\
\hline NDRI * & 212.4 & 205.8 & 139.3 & 57.39 \\
\hline $\mathrm{RNI} * *$ & 320.4 & 327.4 & 395.6 & 60.45 \\
\hline Bunch weight (kg) & 10.1 & 8.2 & 6.3 & 1.38 \\
\hline Actual yield $\left(\mathrm{Mg} \mathrm{ha}^{-1}\right)$ & 1.4 & 1.3 & 1.0 & 0.16 \\
\hline Potential yield $\left(\mathrm{Mg} \mathrm{ha}^{-1}\right)$ & 16.7 & 13.7 & 10.6 & 2.29 \\
\hline Plant height of tallest sucker & 109.0 & 126.3 & 98.1 & 19.63 \\
\hline Pseudostem girth of tallest sucker & 20.8 & 24.8 & 18.3 & 4.58 \\
\hline Number of functional leaves of tallest sucker & 2.6 & 3.1 & 2.3. & 0.71 \\
\hline
\end{tabular}

Both boiled and PIF plants had significantly higher percentages of bunch-producing plants and edible bunches than the untreated. However, the boiled plants recorded a higher percentage of bunch-bearing plants with broken pseudostem than the PIF plants, though the difference was not significant. There were similarities among the sucker types for daughter sucker production but the boiled plants had taller suckers with bigger girth and more leaves than the untreated, yet not different from the PIF. The bush and forest land-use systems were similar in time from planting to flowering and harvesting, percentage of edible bunches, RNI, NDRI, and corm weevil damage. Yet, in the forest there were significantly heavier bunches, probably due to the higher number of living roots and higher proportion of bunch producing plants than in the bush.

\section{Discussion}

Biomass production and weed control potential of planted fallows 
Above-ground biomass yield of $P$. phaseoloides was consistently greater than that of $F$. macrophylla, corroborating earlier results (Nolte \& Weise, 1998; Tarawali et al., 1999) and that $P$. phaseoloides was capable of accumulating about 4.8-7.5 $\mathrm{Mg} \mathrm{ha}^{-1}$ of above-ground dry matter within 6-12 months. Among the villages, the differential biomass yield of $P$. phaseoloides could also be attributed to the rainfall regime because Weber et al. (1997) ascribed poor performance of $P$. phaseoloides to low annual precipitation. On the other hand, the low biomass of F. macrophylla was probably due to the poor establishment of $F$. macrophylla in the field because, elsewhere, with good establishment, typical yields ranged from 8-12 $\mathrm{Mg} \mathrm{ha}^{-1}$ leaf dry matter/year (Asare, 1985; Budelman \& Siregar, 1997).

High biomass production is considered an important attribute of a good weed suppressor (Nair, 1993). Hence, it was not surprising that consistently lowest weed biomass were recorded on P. phaseoloides plots. Hauser \& Norgrove (2001) also observed that $P$. phaseoloides drastically reduced the survival likelihood of plant species in its fallow. By contrast, the unexpectedly high weed biomass in F. macrophylla alleys was related to its compact growth habit than its biomass production. F. macrophylla spreads to just about $1 \mathrm{~m}$ from the centre of the hedgerow and, thus, does not affect the larger proportion of the inter-row space where weeds are found (Hauser, 2002).

Furthermore, MacDicken (1994) indicated that below-ground competition between $F$. macrophylla and adjacent plants was minimal and may, thus, explain the lack of impact on weeds in the alley of the hedgerows. Both $P$. phaseoloides and $F$. macrophylla fallow systems reduced the biomass of the Chromolaena odorata-dominated broad leaf weeds, but the extent of reduction was higher in P.phaseoloides than in F. macrophylla. Munniapan \& Ferrar (1991) indicated that $P$. phaseoloides was an effective cover crop for controlling $C$. odorata. Most grasses are susceptible to shading (Ng et al., 1997) and, therefore, with the climbing habit of $P$. phaseoloides, the grasses were not able to survive, thus, explaining their extremely low mass despite the varying climatic conditions. In effect, $P$. phaseoloides was effective in reducing both broad leaf and grass weeds under varying soil and climatic conditions.

Soil nematodes population under planted and natural fallows

The presence of Helicotylenchus multicinctus and absence of Radopholus similis in the soils at the villages and the land-use systems confirmed reports by Sarah (1989) and Vilardebo \& Guerout (1976) that where $H$. multicinctus was predominant, $R$. similis was generally absent. The initial high population of $H$. multicinctus in the bush natural fallow, dominated by $C$. odorata, suggested that unless $C$. odorata was a host to $H$. multicinctus (personal communication from S. Hauser), it might have provided conditions favourable for $H$. multicinctus through the elimination of other competing nematodes.

The continued increases in $H$. multicinctus numbers in the natural regrowth over the 2-year period of the study further supports the above explanation. Within 1 year of $P$. phaseoloides and $F$. macrophylla growth, lower populations of $H$. multicinctus were found. This could be due to the perturbation of the habitat and the erosion of food resources (Bongers \& Bongers, 1998). Thereafter, when plantain (highly susceptible to the nematode) was planted into each fallow system, there was a slight increase in population of $H$. multicinctus at 24 MAP. However, the resilience of $P$. phaseoloides in limiting the proliferation of the nematode resulted in consistently lower populations of $H$. multicinctus, when the initial population and that at 24 MAP were compared despite the presence of the susceptible crop. This reduced reproduction might be due to a modification of the soil environment by $P$. phaseoloides, thus, making it unfovourable for the development of $H$. multicinctus.

Furthermore, weeds are reported to be hosts to $H$. multicinctus (Queneherve et al., 1995) and $P$. phaseoloides biomass is negatively correlated with total weeds biomass (Banful et al., 2007), thus, partly explaining the reduced $H$. multicinctus numbers observed. In contrast, populations of $H$. multicinctus under F. macrophylla were similar to the initial population over the 2-year period. The apparent lack of nematode reducing effect of $F$. macrophylla could probably be due to the nature of 
its root system, among others. Flemingia macrophylla has a tap root which is not laterally extensive and, in an alley cropping system, where the spaces between the hedgerows are wide, toxic exudates from its roots might not be in sufficient concentrations to effectively inhibit multipli-cation of $H$. multicinctus, an ectoend-oparasite nematode.

The consistently higher $H$. multicinctus population at Ngoumou could be related to the high rainfall experienced which, as determined in this study and corroborated by Cadet et al. (2003), was positively correlated with $H$. multicinctus population. Similar observations were also made in Ivory Coast (Queneherve,1989). On the contrary, Hutton (1978) found, in Jamaica, a negative correlation between soil population and rainfall but, in Nigeria, he found no correlation with rainfall. In the tropics, these discrepancies in the relationships between $H$. multicinctus population and rainfall may be attributed to differences in soil type.

\section{Establishment, growth and yield of plantain under planted and natural fallows}

The over $85 \%$ establishment observed in the study may be due to the sanitization of the PIF and boiled plants against nematodes, thus, ensuring better field establishment and survival. The good growth exhibited by the boiled plants was the result of two phenomena. First, boiling the suckers produced sanitized planting material potentially devoid of nematodes and weevils in the roots and corm, thus, improving nutrient and water uptake. Second, the corm from the mother plant was physiologically mature and, thus, contained more carbohydrate reserves for early crop growth.

In contrast, the growth of the PIF- "Essong" plants, also sanitized, was slow due primarily to their immature corm. The good plantain growth observed under $P$. phaseoloides could be related to the reduced density of $H$. multicinctus which led to unhindered uptake of water and nutrients by the plantain roots from the soil. In addition, the excellent performance of $P$. phaseoloides as a weed suppressor reduced competition for moisture and nutrients between the plantains and weeds. Furthermore, Banful et al. (2007) reported that $P$. phaseoloides decomposed quite fast with high releases of $\mathrm{N}, \mathrm{P}, \mathrm{K}, \mathrm{Mg}$ and $\mathrm{Ca}$, which could have ensured greater nutrient availability to the plantain for enhanced root development and growth.

In general, plantain growth was better at Ngoumou and Mfou than at Nkometou principally due to the good rainfall and, consequently, high moisture availability at these sites. Bhattacharyya \& Rao (1985) stressed the importance of soil moisture in the performance of plantain when they noted that, despite favourable temperature, relative humidity and sunshine during the cropping period, soil moisture deficit adversely affected the growth and yield of plantain. Obiefuna (1988) reiterated that the growth phases of plantain were highly sensitive to adverse growth factors including moisture stress. Furthermore, Cayón et al. (1998) reported 50\% reduction in leaf photo-synthetic rates due to water stress in "Dominico-Hartón" plantain cultivar. Reductions in photosynthesis of waterdeficient plants could lead to reductions in growth and yield.

The low bunch weight of plantain under F. macrophylla could be partly attributed to the consistently high grass density recorded in this fallow system. The plantains under $P$. phaseoloides fallow system had the highest non-damaged root index (NDRI) which was consistent with the low soil nematodes populations under the system. The NDRI generally connoted a healthy root system. The high NDRI indirectly ensured a longer fruit filling period which correlated positively with bunch yield. At the villages, the significantly higher percentage of uprooted plants at Ngoumou than the others was probably due to the higher root damage as indicated by the high RNI. This observation corroborated the significantly high soil population of $H$. multicinctus at Ngoumou. The generally low percentage of bunch-producing plants observed could be due to the low initial soil fertility levels and the erratic nature of the rainfall which could not support rapid plant growth within the period of the study and, therefore, affected the number of plants that could produce bunches.

Both boiled and PIF plants had significantly higher percentages of bunch-producing plants and edible bunches than the untreated, probably due to their higher NDRI and number of living roots. 
Sanitization of the suckers (boiled and PIF) increased actual yield by about 35\%, edible bunches by $26 \%$, and gave indications of early ratooning through faster growth of their daughter suckers. These positive attributes under-scored the importance of planting healthy or clean suckers. The forest had significantly heavier plantain bunches, probably due to the better crop growth, higher number of living roots and a higher proportion of bunch- producing plants than the bush. Ratooning was also expected earlier in the forest than in the bush.

\section{Conclusion}

The study clearly established that Pueraria phaseoloides had the greatest positive effect on the growth and yield of plantain, irrespective of the type of planting material. The positive effect was achieved through suppression of weeds and reduction in the soil population of Helicotylenchus multicinctus, and, consequently, reduced plantain root damage. Flemingia macrophylla and natural regrowth were similar in their effects on the performance of plantain. The synergistic effect of improved soil biological conditions and the use of healthy planting material was clearly evidenced in the yield of the plantain.

\section{Acknowledgement}

Part of the funds for the field experiment was provided by the Belgian Government. B. Banful was funded by an IITA fellowship award. He greatly appreciates the financial support.

\section{References}

Anderson J. M. and Ingram J. S. I. (1993). Tropical soil biology and fertility: a handbook of methods, 2nd edn. CAB International, The Cambrian News, Aberstwyth, United Kingdom. 221 pp.

Asare E. O. (1985). Effects of frequency and height of defoliation on forage yield and crude protein content of Flemingia macrophylla. Proceedings of the XV International Grassland Congress, Kyoto, Japan. pp. 164-165.

Banful B., Hauser S., Ofori K. and Kumaga F. (2007). Weed biomass dynamics in planted fallow systems in the humid forest zone of southern Cameroon Agrofor. Syst. 71 (1): 49-55.

Banful B., Ofori K., Kumaga F., Hauser S. and Ndango, R. (2007). Decomposition and nutrient release patterns of Pueraria phaseoloides, Flemingia macrophylla and Chromolaena odorata leaf residue in tropical land use systems. Ghana Jnl agric. Sci. (In press).

Bhattacharyya R. K. and Rao V. N. M. (1985). Influence of meteorological parameters and the cropping of banana grown under soil covers and soil moisture regimes. Banana Newsl. 8: 7-8.

Bongers T. and Bongers M. (1998). Functional diversity of nematodes. Appl.Soil Ecol. 10: 239-251.

Bridge J. and Gowen S. R. (1993). Visual assessment of plant parasitic nematode and weevil damage on bananas and plantain. In Biological and Integrated Control of Highland Banana and Plantain Pests and Diseases. (C. C. Gold and B. Gemmill, ed.), pp. 147-154. Proceedings of a Research Coordination Meeting. International Institute of Tropical Agriculture, Ibadan, Nigeria.

Broadley R. A. (1979). A simple method for estimating banana root rot. Aust. Pl. Pathol. 8: 24-25.

Budelman A. and Siregar M. E. (1997). Flemingia macrophylla (Willd.) Merrill. In Auxiliary plants. PROSEA (Plant Resources of South-East Asia) No. 11. (I. Faridah Hanum and L. J. G. van der Maesen, ed.), pp. 144-147. Backhuys Publishers, Leiden, Netherlands.

Buondonno A., Rashad A. A. and Coppola E. (1995). Comparing tests for soil fertility. II. The hydrogen peroxide/sulfuric acid treatment as an alternative to the copper/selenium catalyzed digestion process for routine determination of soil nitrogen-Kjeldahl. Communs Soil Sci. Pl. Anal. 26: 1607-1619.

Cadet P., Pate E. and N'Diaye-Faye N. (2003). Nematode community changes and survival rates under natural fallow in the sudano-sahelian area of Senegal. Pedobiologia 47: 1-12.

Cayón M. G., El-Sharkawy M. A. and de Tafur S. M. (1998). Efectos fisio lógicos del estrés hidrico en el clon de plátano Dominico-Hartón (Musa AAB Simmonds). Infomusa 7(2): 12-14.

Dury S., Bricas N., Tchango-Tchango J., Temple L. and Bikoi A. (2002). The determinants of urban plantain consumption in Cameroon. Fd Qual. Prefer. 13: 81-88.

Hauser S. (2002). Volunteer biomass production between multipurpose tree hedgerows after two years of fallow in southern Cameroon. Agrofor. Syst. 55: 139-147.

Hauser S. and Norgrove L. (2001). Slash-and-burn agriculture, Effects of. Encyclopaedia of Biodiversity 5: 269-284.

Heanes D. L. (1984). Determination of organic C in soils by an improved chromic acid digestion and spectro-photometric procedure. Communs Soil Sci. Pl. Anal. 15: 1191-1213.

Hoopers D. J. (1990). Extraction and processing of plant and soil nematodes In Plant parasitic nematodes in sub-tropical and tropical agriculture. (M. Luc, R. A. Sikora and J. Bridge, ed.), pp. 45-68. CAB International, Wallingford, UK.

Hulugalle N. R. and Ndi N. J. (1993). Effects of no-tillage and alley cropping on soil properties and crop yields in a Typic Kandiudult of southern Cameroon. Agrofor. Syst. 22: 207-220. 
Hutton D. G. (1978). Influence of rainfall on some plantain nematodes in Jamaica. Nematropica 8: 34-39.

Kang B. T., Salako F. K., Akobundu I. O., Pleysier J. L. and Chianu J. N. (1997). Amelioration of a degraded Oxic Paleustalf by leguminous and natural fallows. Soil Use Mgmt 13: 130-136.

Kumar N., Krishnamoorthy V., Nalina L. and Soorianathasundharam K. (2001). A new factor for estimating total leaf area in banana. Infomusa 11 (2): 42-43.

MacDicken K. G. (1994). Selection and management of nitrogen fixing trees. Winrock International, Morrilton, Arkansas, USA.

Mehlich M. (1984). Mehlich-3 soil test extractant: a modification of the Mehlich-2 extractant. Communs Soil Sci. Pl. Anal. 15: 1409-1416.

Muniapan R. and Ferrar P. (1991). Ecology and management of Chromolaena odorata. Proc. 2nd Int. Workshop on Biological Control of Chromolaena odorata, Bogor, Indonesia, 1991. BIOTROP Spec. Publ. No. 44, Bogor, Indonesia.

Murphy J. and Riley J. P. (1962). A modified single solution method for determination of phosphate in natural waters. Analytica chim. Acta 27: 31-36.

Nair P. K. R. (1993). An introduction to Agroforestry. Kluwer Academic Publishers, Dordrecht, the Netherlands.

Ng K. F., Stur W. W. and Shelton H. M. (1997). New forage species for integration of sheep in rubber plantations. J. agric. Sci. Camb. 128: 347-355.

Nolte C. and Weise S. (1998). Screening herbaceous and shrub legumes for short planted fallows in maize systems. In Short fallow systems to arrest resource degradation due to land-use intensification, pp. 24-30. Project Report. Int. Inst. of Trop. Agric., Ibadan, Nigeria.

Obiefuna J. C. (1988). The effect of climatic conditions on the growth and yield of False horn plantains (Musa AAB). Biol. Agric. Hort. 4: 349-354.

Ortiz R. and Vuylsteke D. (1996). Improving plantain- and banana-based systems. In Plantain and banana production and research in West and Central Africa. (R. Ortiz and M. O. Akoroda, ed.), pp. 2-7. Proceedings of a regional workshop held at High Rainfall Station, Onne, Rivers State, Nigeria. International Institute of Tropical Agriculture (IITA), Ibadan , Nigeria.

Pasberg-Gauhl C. and Gauhl F. (1996). Musa spp. research in the plant health management division at IITA: activities at the high rainfall station, Onne in Nigeria. In Plantain and Banana Production and Research in West and Central Africa. (R. Ortiz and M.O. Akoroda, ed.), pp. 7-14. Proceedings of a regional workshop held at High Rainfall Station, Onne, Rivers State, Nigeria. International Institute of Tropical Agriculture (IITA), Ibadan, Nigeria.

Queneherve P. (1989). Population of nematodes in soils under banana cv. Poyo in the Ivory Coast. 3. Seasonal dynamics of populations in mineral soil. Revue Nematol. 12: 149-160.

Queneherve P., Drob F. and Topart P. (1995). Host status of some weeds to Meloidogyne spp., Helicotylenchus spp. and Rotylenchulus reniformis associated with vegetable cultivated in polytunnels in Martinique. Nematropica 25: 149157.

Robinson J. C. (2000). Banana productivity: The impact of agronomic practices. Proc. Int. Symp. on Banana and Plantain for Africa. (K. Craenen et al., ed.) Acta Hort. 540: 247-258. ISHS.

Robinson J. C. (1996). Bananas and plantain. CAB International, Wallingford, UK.

Sarah J- L. (1989). Banana nematodes and their control in Africa. Nematropica 19: 199-215.

SAS Institute. (1997). SAS/STAT Software: Changes and Enhancements through Release 6.12. Cary, NC, USA.

SAS Institute (1989). SAS/STAT User Guide, 4th edn. SAS Institute Inc., Cary, NC, USA.

Schill P., Gold C. S. and Afreh-Nuamah K. (1996). Assessment and characterization of constraints in plantain production in Ghana as an example for West Africa. In Plantain and Banana Production and Research in West and Central Africa. (R. Ortiz and M. O. Akoroda, ed.), pp. 45-51. Proceedings of a regional workshop held at High Rainfall Station, Onne, Rivers State, Nigeria. International Institute of Tropical Agriculture (IITA), Ibadan, Nigeria.

Tarawali S. A., Peters M. and Schultze-Kraft R. (1999). Forage legumes for sustainable agriculture and livestock production in sub-humid West Africa. Int. Livestock Res. Inst. Project report. ILRI, Nairobi, Kenya.

Thenkabil P. S. (1999). Characterization of the alternative to slash-and-burn benchmark research area representing the Congolese rainforests of Africa using Near-Real-Time SPOT HRV data. Int. J. Rem. Sens. 20: 839-877.

Vilardebo A. and Guerout R. (1976). Nematodes species in West Africa, Madagascar and Reunion with some comments on their biology. Nematropica 6: 53-54.

Weber G. K., Robert A. B. C. and Carsky R. (1997). LEXSYS 2.1, Decision support for the integration of legumes into tropical farming systems. Int. Inst. of Trop. Agric., Ibadan, Nigeria. 